\title{
Pemberdayaan Komunitas Peduli Lingkungan Melalui PKM Kubermas Tahap 1 di Universitas Khairun
}

\author{
Abdulrasyid Tolangara', Abdu Mas'ud ${ }^{* 2}$, Sundari $^{3}$ \\ abdumasud@unkhair.ac.id*2, sundari@unkhair.ac.id ${ }^{3}$ \\ 1,2,3 Prodi Pendidikan Biologi, FKIP, Universitas Khairun
}

\begin{abstract}
Received: 20 October 2021 Accepted: 22 December 2021 Online Published: 31 December 2021
DOI: 10.29408/ab.v2i2.4105
\end{abstract}

\begin{abstract}
Abstrak: Kubermas (Kuliah Berkarya Bermasyarakat) merupakan salah satu program intrakurikuler yang adakan oleh Universitas Khairn. Bentuk kegiatannya berupa kegiatan pengabdian sebagai wujud pelaksanaan Tri Dharma Perguruan Tinggi. Pada tahap 1, program utama kegiatan PKM Kubermas ini adalah pemberdayaan masyarakat untuk melaksanakan konservasi tanaman rempah dan herba kebun pekarangan rumah. Lokasi kegiatan di Kampus 1 FKIP kelurahan Akehuda, kota Ternate Utara, dan RT 14 Kelurahan Kayu Merah, kota Ternate Selatan. Tujuan PKM Kubermas ini adalah 1) untuk membentuk komunitas masyarakat yang memiliki kepekaan untuk menanam dan merawat serta memanfaatkan tanaman rempah dan herba pekarangan rumah sebagai upaya konservasi; 2) memberikan pengalaman langsung kepada mahasiswa peserta Kubermas dalam program pemberdayaan masyarakat di lokasi Kubermas. Metode pengabdian adalah partisipatoris masyarakat dan pelatihan. Hasil pengabdian masyarakat ini adalah pengetahuan masyarakat tentang konservasi rempah dan herba pekarangan rumah serta pengetahuan pemanfaatan rempah dan herba pekarangan rumah pada pembuatan Hand Sanitizerberbahan tanaman herbal dan Rorano di masa pandemi. Mahasiswa memiliki pengalaman langsung metode pendampingan masyarakat dan pemanfaatan kebun pekarangan rumah.
\end{abstract}

Kata kunci: Kubermas; Ramuan Rorano ; Tanaman Herbal

Abstract: Kubermas (Community Work Lecture) is one of the intracurricular programs organized by Khairn University. The form of activity is in the form of service activities to implement the Tri Dharma of Higher Education. In phase 1, the main program of this Kubermas PKM activity is community empowerment to carry out the conservation of spices and herbs in home gardens. The activity location is on Campus 1 of FKIP, Akehuda subdistrict, North Ternate city, and RT 14, Kayu Merah sub-district, South Ternate city. The objectives of the Kubermas PKM are 1) to form a community of people who have the sensitivity to plant and care for and utilize herbs and spices in the yard of the house as a conservation effort; 2) provide direct experience to students participating in Kubermas in community empowerment programs at Kubermas locations. The method of service is community participation and training. The results of this community service are public knowledge about the conservation of home garden spices and herbs and knowledge of the use of home garden spices and herbs in the manufacture of Hand Sanitizermade from herbs and Rorano during the pandemic. Students have direct experience of community assistance methods and the use of home gardens.

Keywords: Herbal Plant; Kubermas; Rorano's Concoction 
Tolangara, A. R., Mas'ud, A., Sundari, S. (2021). Pemberdayaan komunitas peduli lingkungan melalui PKM Kubermas tahap 1 di Universitas Khairun. ABSYARA: Jurnal Pengabdian Pada Masyarakat, 2(2), 311-317. doi:10.29408/ab.v2i2.4105

\section{PENDAHULUAN}

Kebun dan pekarangan rumah masyarakat di pulau Ternate sangat kaya dengan potensi rempah dan herba yang jika dikelola dengan baik akan memberikan dampak bagi kesejahteraan dan kesehatan keluarga (Rahman, 2019; Hasan, dkk., 2021). Sejauh ini, potensi medik dari berbagai jenis-jenis rempah dan tetumbuhan telah dikenali dengan baik, namun apresiasi masyarakat dan upaya-upaya pengembangan tanaman rempah dan herba dalam bentuk peruntukan lainnya masih kurang diperhatikan masyarakat (Hakim, 2014; Kandowangko, 2014). Fenomena di lapangan, keanekaragaman hayati kebun dan pekarangan rumah terancam karena laju pertumbuhan penduduk dan permintaan masyarakat akan lahan untuk kegiatan ekonomi rumah tangga dan lainnya (Fatmawati, dkk., 2020). Di sisi lain kepedulian masyarakat terhadap kelestarian tanaman juga semakin menurun seiring dengan perkembangan teknologi dan perubahan iklim (Manik, 2018). Perlunya upaya konservasi rempah berdasarkan analisa situasi bahwa terdapat fenomena pohon cengkeh kering meranggas dan kebun pala yang kurang produktif di beberapa tempat di pulau Ternate (Sundari, dkk., 2020).

Berdasarkan analisis situasi di atas maka dapat dirumuskan beberapa solusi terhadap permasalahan yang ada di pulau Ternate berkaitan dengan fenomena perlunya upaya konservasi rempah dan herba pekarangan rumah. Adapun solusi yang dimaksud adalah pendampingan inventarisasi rempah dan herba pekarangan rumah di pulau Ternate berbasis data etnoagroekonomi. transfer teknologi restorasi rempah pulau Ternate melalui program kemitraan antara Universitas Khairun dalam hal ini dosen Prodi pendidikan Biologi dengan mitra yaitu masyarakat pulau Ternate. Kemitraan terjalin melalui pelaksanaan program PKM Mandiri integrasi KUBERMAS tahun 2021.

Program kemitraan ini bertujuan untuk melakukan konservasi rempah dan herba pekarangan rumah masyarakat di kota Ternate khususnya di kelurahan Tarau melalui inventarisasi rempah dan herba pekarangan rumah berbasis etnoagroekonomi . Selain itu program ini diharapkan dapat menghasilkan luaran kompetensi masyarakat pulau Ternate untuk dapat melakukan konservasi rempah dan herba pekarangan rumah. Selanjutnya program ini dapat dikembangkan kemitraannya dengan dinas dan instansi terkait

Program ini dilaksanakan di kelurahan yang memiliki potensi rempah dan herba pekarangan rumah yaitu pala dan cengkeh serta herba pekarangan rumah masyarakat. Lokasi sasaran adalah kelurahan Kayu Merah. Pada kelurahan Kayu Merah terdapat perkebunan rempah dan herba pekarangan rumah, perkebunan cengkeh, pala dan herba pekarangan rumah pada saat ini mulai berkurang karena aktivitas pembangunan gedung dan perumahan. Kondisi sosial masyarakat heterogen atau multikulturlah karena tercampur dengan pendatang dari luar baik masyarakat pedagang ataupun wisatawan ke Benteng Kalamata dan spot pariwisata di kelurahan Kayu Merah.

Berdasarkan permasalahan tersebut di atas, maka perlu dilakukan langkah-langkah strategis untuk menyelesaikan konservasi herba dan rempah sebagai upaya meningkatkan daya dukung lingkungan, dan sekaligus menyelesaikan masalah ketahanan pangan dan obat keluarga melalui program "Pemberdayaan Masyarakat Peduli lingkungan melalui Pemanfaatan kebun Pekarangan rumah untuk Konservasi rempah di Kelurahan Kayu merah dan kampus FKIP Unkhair". Program semacam ini merupakan program yang didasarkan pada inisiatif lokal, yang merupakan bagian dari model-model pembangunan yang dapat menyejahterakan masyarakat desa. Program pembangunan masyarakat ini tidak berpusat pada birokrasi melainkan berpusat 
pada masyarakat atau komunitasnya sendiri. Pemberian kekuasaan pada inisiatif lokal dan partisipasi masyarakat menjadi kata kunci dalam pengembangan masyarakat (Sarjono \& Trilaksono, 2008).

\section{METODE PELAKSANAAN}

\section{Waktu dan Lokasi}

Program ini berlangsung selama 4 minggu yaitu dari bulan Agustus sampai dengan September 2021. Lokasi pengabdian di kelurahan Kayu merah khususnya RT 014 dan di Kampus 1 FKIP Universitas Khairun.

\section{Prosedur pelaksanaan}

Pelaksana program PKM ini terdiri dari 2 orang dosen dan 20 orang mahasiswa peserta KUBERMAS di FKIP dan 43 Mahasiswa KUBERMAS di Kelurahan Kayu Merah. Mitra terdiri dari Pihak Kelurahan Kayu Merah dan kelompok pemuda pemilik kebun cengkeh dan pala di pulau Ternate. Adapun tahap-tahap yang dilakukan adalah sebagai berikut: 1) Pelatihan inventarisasi rempah dan pemanfaatannya berdasarkan etnoagroekonomi; 2) Pelatihan teknologi restorasi rempah; 3) Pendampingan pelaksanaan program inventarisasi dan restorasi; 4) Evaluasi dan persiapan tindak lanjut dan pelaporan.

\section{HASIL DAN PEMBAHASAN \\ HASIL}

1. Pelaksanaan inventarisasi tanaman rempah dan herba pekarangan rumah di RT 14 kelurahan kayu Merah dan kampus 1 FKIP, hasil diperoleh informasi bahwa pada pekarangan rumah warga RT 014 di kelurahan Kayu merah masih belum optimal dimanfaatkan dengan ditanami tanaman obat dan sayur serta rempah-rempah kebun pekarangan rumah. Di kampus FKIP juga belum ada lokasi kebun percontohan konservasi herba pekarangan rumah.

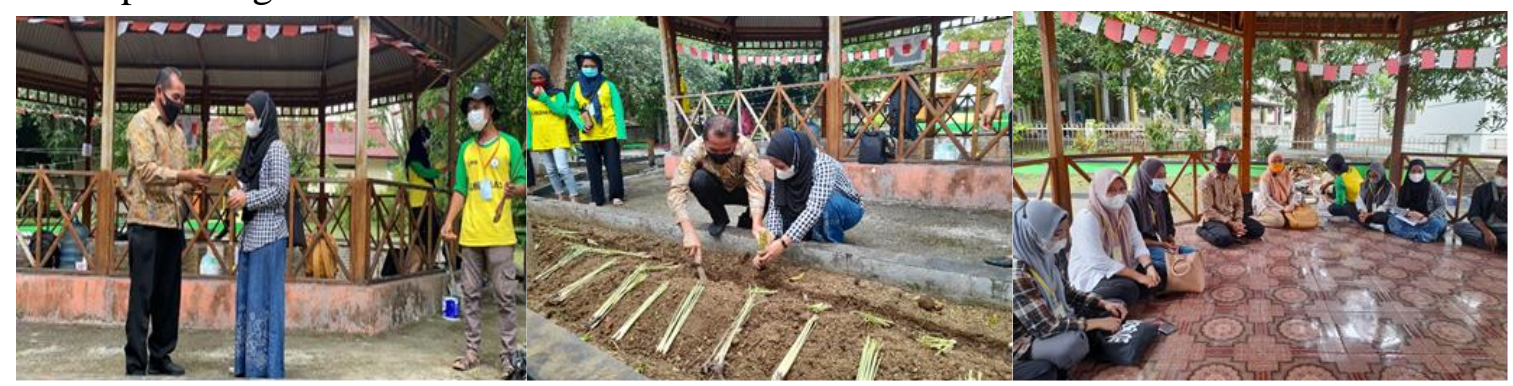

Gambar 1. Kegiatan Konservasi herba dan rempah pekarangan rumah di FKIP Unkhair

2. Penyuluhan dan penanaman tanaman rempah dan Herba pekarangan rumah, oleh tim PKM dan mahasiswa Kubermas kepada warga RT 014 kelurahan kayu merah dan kepada mahasiswa Kubermas di lokasi FKIP Unkhair agar memiliki kesadaran dan kemauan untuk peduli melakukan konservasi tanaman herba dan rempah kebun pekarangan rumah. 


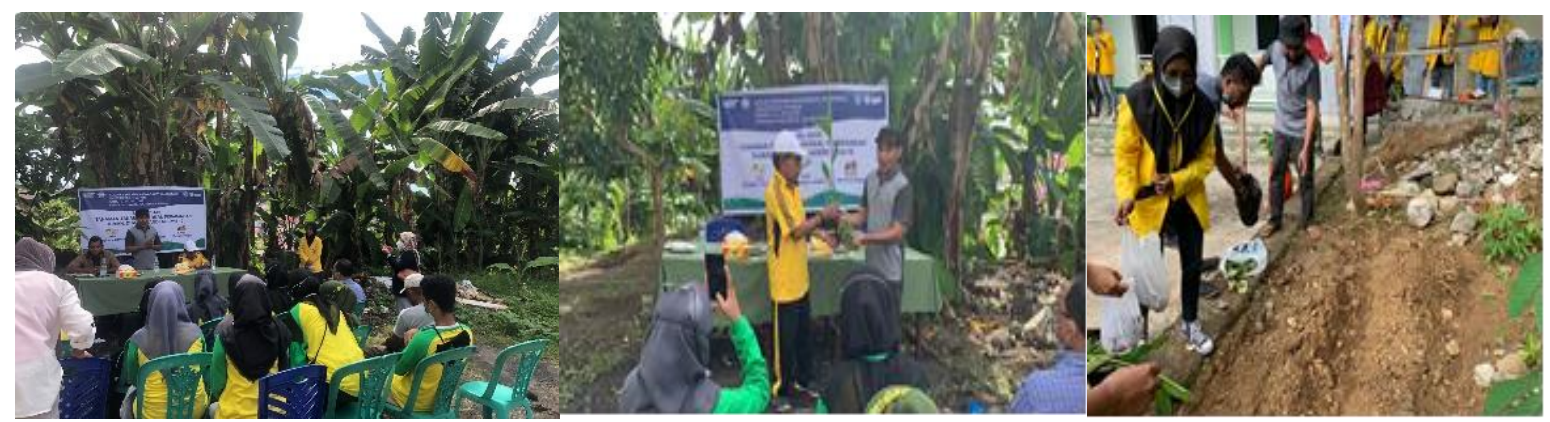

Gambar 2. Kegiatan Konservasi herba dan rempah pekarangan rumah di Kelurahan Kayu

Merah

3. Penyuluhan dan praktik pemanfaatan tanaman herba pekarangan rumah dengan membuat Hand Sanitizer ekstrak sirih lidah buaya. Penyuluhan pemanfaatan tanaman herbal untuk mendukung kesehatan di masa pandemi dengan membuat rorano ekstrak jahe sere dan lengkuas.

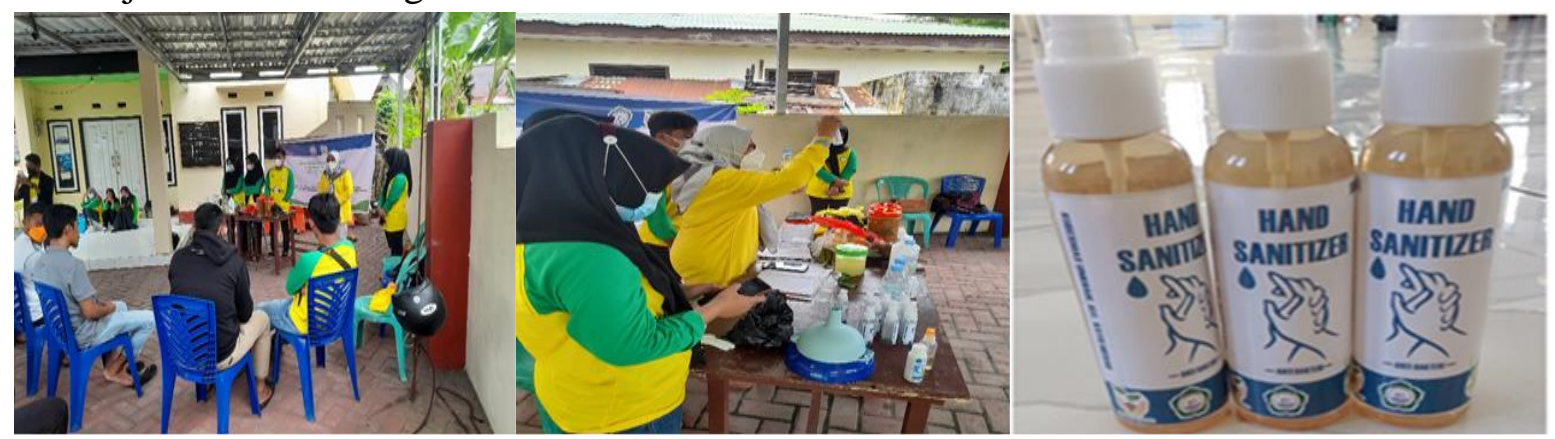

Gambar 3. Penyuluhan Pemanfaatan tanaman herba pekarangan rumah di Kelurahan Kayu Merah

4. Analisis respons mahasiswa KUBERMAS terhadap keterlaksanaan program konservasi herba pekarangan rumah seperti Tabel 1:

Tabel 1. Pengetahuan dan Sikap mahasiswa terhadap kegiatan PKM

\begin{tabular}{clcl}
\hline No. & \multicolumn{1}{c}{ Aspek } & Persentase & \multicolumn{1}{c}{ Keterangan } \\
\hline $\mathbf{1}$ & $\begin{array}{l}\text { Mahasiswa memahami tentang } \\
\text { tanaman herba pekarangan rumah }\end{array}$ & $86 \%$ & $\begin{array}{l}\text { Inventarisasi dan } \\
\text { penanaman herba sesuai } \\
\text { kebutuhan }\end{array}$ \\
$\mathbf{2}$ & $\begin{array}{l}\text { Mahasiswa memahami manfaat } \\
\text { tanaman herba pekarangan rumah }\end{array}$ & $91 \%$ & $\begin{array}{l}\text { Penyuluhan pembuatan } \\
\text { Hand Sanitizer dan rorano }\end{array}$ \\
$\mathbf{3} \quad \begin{array}{l}\text { Mahasiswa mampu mentransfer } \\
\text { informasi pada masyarakat } \\
\mathbf{4}\end{array}$ & $78 \%$ & $\begin{array}{l}\text { Penyuluhan dan sosialisasi } \\
\text { langsung dari program ini }\end{array}$ \\
\end{tabular}

Berdasarkan data di atas dapat diketahui bahwa rata-rata mahasiswa memahami tentang konservasi herba pekarangan rumah. Mahasiswa juga mampu mentransfer informasi terkait perlunya program konservasi herba pekarangan rumah. Selanjutnya diketahui respons masyarakat sasaran program rata-rata memberikan respon program ini bermanfaat dan perlu dilakukan. 
Sedangkan respons dari masyarakat terhadap program konservasi herba pekarangan rumah seperti Tabel 2 berikut ini:

Tabel 2. Feedback Masyarakat Mitra

\begin{tabular}{clllr}
\hline No. & \multicolumn{1}{c}{ Aspek } & Persentase & \multicolumn{2}{c}{ Keterangan } \\
\hline $\mathbf{1}$ & $\begin{array}{l}\text { Materi penyuluhan herba } \\
\text { pekarangan rumah Jelas dan } \\
\text { bermanfaat }\end{array}$ & & $\begin{array}{l}\text { Inventarisasi } \\
\text { penanaman herba sesuai } \\
\text { kebutuhan }\end{array}$ \\
$\mathbf{2}$ & $\begin{array}{l}\text { Materi penyuluhan } \\
\text { pemanfaatan herba untuk } \\
\text { Hand Sanitizer dan Rorano } \\
\text { jelas }\end{array}$ & $95 \%$ & $\begin{array}{l}\text { Penyuluhan pembuatan } \\
\text { Hand Sanitizer dan rorano }\end{array}$ \\
\hline
\end{tabular}

Berdasarkan tabel 2 diketahui bahwa rata-rata 94\% masyarakat memberikan respon positif terhadap program konservasi herba dan rempah pekarangan rumah. Pekarangan merupakan salah satu bentuk wanatani yang kompleks dengan struktur dan komposisi spesies yang sangat beragam. Pekarangan rumah merupakan salah satu praktik agroforestri yang memiliki karakteristik esensial. Pekarangan rumah memenuhi prinsip ekologi dan sosial dimana pohon, tanaman semusim, tanaman hias, serta tanaman dan ternak lainnya dapat hidup bersama. Konsep pemanfaatan pekarangan secara berkelanjutan memiliki dua dimensi: peran positif dalam memenuhi kebutuhan untuk merespons perubahan sosial ekonomi masyarakat dan pelestarian alam.

\section{PEMBAHASAN}

Kebun pekarangan rumah memiliki fungsi multiguna, sebagai tempat menanam bahan pangan seperti umbi-umbian, sayur, buah-buahan; bahan tanaman rempah dan obat, bahan kerajinan tangan; bahan pangan hewani yang berasal dari unggas, ternak kecil maupun ikan; tanaman hias, bahan bangunan, kayu bakar dan pakan ternak (Mahmudah, dkk., 2020). Manfaat yang akan diperolah dari pengelolaan kebun pekarangan rumah antara lain dapat: memenuhi kebutuhan konsumsi dan gizi keluarga, menghemat pengeluaran, dan juga dapat memberikan tambahan pendapatan bagi keluarga (Amruddin \& Iqbal, 2018). Selain itu, kebun pekarangan rumah dapat memberikan fungsi konservasi jenis yang terancam punah. Kebun pekarangan rumah juga memiliki fungsi sosial penting melalui pemberian hadiah produk pekarangan untuk silaturahmi, membantu pengobatan dan acara keagamaan (Butarbutar \& Kandou, 2018).

Program pemanfaatan kebun pekarangan rumah di kelurahan Kayu merah ini dapat memiliki tiga manfaat secara sekaligus, yakni peningkatan nilai-nilai konservasi, nilai ekonomi, dan nilai ketahanan pangan (Thesiwati, 2020). Adapun selengkapnya dijelaskan sebagaimana uraian berikut: 1) Nilai konservasi, yakni konservasi lingkungan, dimana tanah pekarangan dapat digunakan sebagai daerah resapan air melalui pembuatan lubang resapan biopori, sehingga setiap rumah tangga akan mampu melakukan konservasi air. Hal ini akan membantu recharges air ke dalam tanah sehingga akan menjadi cadangan untuk kebutuhan masyarakat pada saat musim kemarau yang kering. 2) Nilai ekonomi, yakni melalui peningkatan wirausaha agribisnis, dimana pemanfaatan lahan pekarangan dengan penanaman tanaman hortikultura 
seperti sayuran, bumbu-bumbu dapur, dan buah-buahan akan mendatangkan keuntungan ekonomi bagi keluarga. 3) Nilai ketahanan pangan, melalui penanaman tanaman hortikultura seperti sayuran, bumbu-bumbu dapur, dan buah-buahan akan menjamin ketahanan pangan keluarga. Apalagi sayuran dan tanaman bumbu dapur seperti cabai, merupakan bahan pokok yang dikonsumsi setiap hari.

Program pengabdian kepada masyarakat integrasi KUBERMAS di kelurahan Kayu merah dapat memberi manfaat kepada daerah sasaran selaku mitra KUBERMAS salah satunya dapat tercipta daerah penyangga akan mendukung program konservasi wilayah; 2) Kelurahan Kayu merah mendapatkan manfaat sosial sebagai wilayah sasaran program KUBERMAS kampus; 3) Program pemanfaatan kebun pekarangan rumah ini merupakan upaya tindak lanjut dari Program Unggulan KUBERMAS yang sebelumnya telah menjadi sasaran KUBERMAS sektor Wisata Benteng Kalamata.

\section{SIMPULAN}

Hasil pengabdian masyarakat ini adalah pengetahuan masyarakat tentang konservasi rempah dan herba pekarangan rumah serta pengetahuan pemanfaatan rempah dan herba pekarangan rumah pada pembuatan Hand Sanitizer berbahan tanaman herbal dan rorano di masa pandemi. Mahasiswa memiliki pengalaman langsung metode pendampingan masyarakat dan pemanfaatan kebun pekarangan rumah

\section{PERNYATAAN PENULIS}

Pernyataan dan komitmen bersama dari penulis bahwa artikel ini belum pernah dipublish pada jurnal yang lain

\section{DAFTAR PUSTAKA}

Amruddin, A., \& Iqbal, M. (2018). pemanfaatan lahan pekarangan sebagai upaya pemenuhan kebutuhan keluarga di Desa Kanjilo Kecamatan Barombong Kabupaten Gowa. ZIRAA'AH MAJALAH ILMIAH PERTANIAN, 43(1), 70-76.

Butarbutar, R. R., \& Kandou, F. E. F. (2018). Usahatani tanaman hias dalam mendukung upaya konservasi dan keanekaragaman hayati di Kakaskasen Tomohon. Jurnal LPPM Bidang Sains dan Teknologi, 4(2), 16-25.

Fatmawati, B., Adriandani, N., \& Fajri, N. (2020). Edukasi Zat Aditif Melalui Demonstrasi Kimia di MA NW Ridlol Walidain Batu Bangka. ABSYARA: Jurnal Pengabdian Pada Masyarakat, 1(1), 1-9.

Hakim, L. (2014). Etnobotani dan manajemen kebun-pekarangan rumah. Jawa Timur: Penerbit Selaras.

Hasan, S., Mas'ud, A., \& Sundari, S. (2021). Etnopedagogy Approach To Science Learning In Sdn 50 City Of Ternate Based On The Local Wisdom Of Rempah North Maluku. Pedagonal: Jurnal Ilmiah Pendidikan, 5(2), 133-141.

Kandowangko, N. Y. (2014). Kajian Etnobotani Tanaman Obat Oleh Masyarakat Kabupaten Bonebolango Provinsi Gorontalo. Penelitian Unggulan Pusat Studi, 2(737). 
Mahmudah, R., Abdullah, A., Rodiyah, H., \& Susilawati, S. (2020). Pemberdayaan Limbah Serabut Kelapa Menjadi Pobuke Berbasis Geometri Untuk Menaggulangi Tingkat Pengagguran Di Desa Senyiur. ABSYARA: Jurnal Pengabdian Pada Masyarakat, 1(1), 33-34.

Manik, K. E. S. (2018). Pengelolaan lingkungan hidup. Kencana.

Rahman, F. (2019). “Negeri Rempah-rempah” dari Masa Bersemi Hingga Gugurnya Kejayaan Rempah-rempah. Patanjala, 11(3), 291735.

Sundari, S., Taher, D. M., Nurhasanah, N., Mas' ud, A., \& Hasan, S. (2020). Pendampingan pembuatan hand sanitizer berbasis kearifan lokal (ekstrak tangkai bunga cengkeh). ABSYARA: Jurnal Pengabdian Pada Masyarakat, 1(2), 49-55.

Thesiwati, A. S. (2020). Pemanfaatan Lahan Pekarangan Sebagai Pangan Lestari di Masa Covid-19. Jurnal Pengabdian Kepada Masyarakat Dewantara, 3(2 Septembe), 25-30. 